J Insect Physiol. 2007 May ; 53(5): 399-410. doi:10.1016/j.jinsphys.2007.01.010.

\title{
Flight and fight:
}

\section{A comparative view of the neurophysiology and genetics of honey bee defensive behavior}

\author{
G.J. Hunt ${ }^{*}$ \\ Department of Entomology, Purdue University, 901 W. State St., West Lafayette, IN 47907, USA
}

\begin{abstract}
Honey bee nest defense involves guard bees that specialize in olfaction-based nestmate recognition and alarm-pheromone-mediated recruitment of nestmates to sting. Stinging is influenced by visual, tactile and olfactory stimuli. Both quantitative trait locus (QTL) mapping and behavioral studies point to guarding behavior as a key factor in colony stinging response. Results of reciprocal F1 crosses show that paternally inherited genes have a greater influence on colony stinging response than maternally inherited genes. The most active alarm pheromone component, isoamyl acetate (IAA) causes increased respiration and may induce stress analgesia in bees. IAA primes worker bees for 'fight or flight', possibly through actions of neuropeptides and/or biogenic amines. Studies of aggression in other species lead to an expectation that octopamine or 5-HT might play a role in honey bee defensive response. Genome sequence and QTL mapping identified 128 candidate genes for three regions known to influence defensive behavior.

Comparative bioinformatics suggest possible roles of genes involved in neurogenesis and central nervous system (CNS) activity, and genes involved in sensory tuning through G-protein coupled receptors (GPCRs), such as an arrestin (AmArr4) and the metabotropic $\mathrm{GABA}_{\mathrm{B}}$ receptor (GABAB-R1).
\end{abstract}

\section{Keywords}

Aggressive behavior; Apis mellifera; Behavior genetics; Tango; 14-3-3 epsilon; Homer; PKA;

Neuromodulator; Biogenic amine; Darkener of apricot

\section{Introduction}

Understanding the underlying cause of aggression in humans is an important problem that has benefited from the use of non-human models. With a newly sequenced genome, the honey bee offers an opportunity to study aggression in a social insect. Within insect societies, natural selection operates not just at the level of the individual, but also at the level of the colony, which favors specialization and cooperation (reviewed by Wilson, 1971). As with human societies, bees have "soldiers" that die in defense of the colony. The honey bee colony is genetically diverse because the queen mates with about 12-17 haploid males (drones). A drone transmits an identical genome to each of his daughters, resulting in genetically divergent patrilines that often differ in their tendency to perform particular tasks (e.g., Frumhoff and Baker, 1988; Page and Robinson, 1991). If too many bees participate in a stinging response, the labor force of the colony would be depleted. Honey bees use an early-warning system in which some individuals detect threats and recruit nestmates to defend the nest. Neotropical Africanized honey bees (AHB) are derived from the subspecies Apis mellifera scutellata and

\footnotetext{
*Corresponding author. Tel.: +1 765494 4605; fax: +1 765494 0535. E-mail address: ghunt@purdue.edu.
} 
exhibit a higher level of defensive behavior in comparison to most European honey bee (EHB) races (Collins et al., 1982). AHB in the neotropics represent an admixture of races but appear to retain much of the African genotype and highly defensive phenotype of the introduced population (Schneider et al., 2004; Whitfield et al., 2006).

The defensive response consists of several specific behavior patterns of worker bees: stinging, guarding and pursuing (reviewed by Breed et al., 2004). These behaviors originate near the nest. Nest defense also involves recruitment through alarm pheromone. The early-warning system of the colony consists of guards in the nest entrance and several studies have emphasized the role of guards in the stinging response. Guard bees inspect incoming bees and other arthropods, and show a typical alert posture. They approach incoming bees and may fly up at a moving visual cue. Guards that are alerted by physical disturbance or agonistic encounter often extrude their sting causing release of alarm pheromone (Maschwitz, 1964). Guards engage in non-associative (unrewarded) learning; they learn to recognize nestmates based on olfactory cues from cuticular hydrocarbons (Breed et al., 1995). Non-nestmates are rejected by biting or stinging. Guard bees are a small minority of the bees that respond by stinging moving targets at the hive entrance but the number of guards in the entrance correlates with the colony stinging response and removal of guards temporarily reduces the response (Arechavaleta-Velasco and Hunt, 2003). Workers usually guard for just one to several days (Breed et al., 1988). Colonies with workers that guard for longer periods show greater stinging responses than colonies with less persistent guards (Breed and Rogers, 1991; Hunt et al., 2003a).

Interactions between nestmates are an important aspect of colony defense. For example, interactions between individuals can increase the stimulus for guarding. In mixed-genotype hives, AHB exhibited increased guarding behavior in colonies containing high proportions of AHB. Individual EHB were relatively unaffected by genotypic interactions but were less likely to initiate guarding in high-AHB hives (Hunt et al., 2003a). Similar interactions occurred in small- and large-population hives, but both AHB and EHB were more persistent at guarding in large colonies. The positive feedback on guarding behavior could be explained by either releaser or primer effects of alarm pheromone (see below) or perhaps the act of guarding causes release of neurohormones (neuropeptides or biogenic amines) that reinforce the behavior. Interactions are also important for recruitment to sting. AHB were $81 \%$ of the first few bees to sting leather flags waived directly over small, open colonies composed of $50 \%$ of each bee type. But after ten seconds of stinging activity, European nestmates were as likely to sting as African-derived bees. This phenomenon apparently was caused by recruitment, and not by the slower reaction times of EHB, since large source colonies from which these European bees were originally obtained never stung in assays repeated eight times, even though large colony populations greatly increase stinging responses (Guzmán-Novoa et al., 2004).

\section{Alarm pheromones}

Beekeepers are familiar with the banana-like odor of the principal active compound of honey bee alarm pheromone, isoamyl acetate, or IAA and use smoke to reduce defensive responses. Smoke reduces the stimulation of olfactory receptor neurons in the presence of IAA as measured by electroantennograms (EAGs; Visscher et al., 1995). Over 40 aliphatic and aromatic compounds have been identified in the alarm pheromone blend that is produced primarily in the Koshewnikov gland associated with the sting apparatus. The adaptive significance of this complexity is unknown (Blum and Fales, 1988; Lensky and Cassier, 1995; Slessor et al., 2005). The mandibular glands of workers also produce a compound, 2heptanone, which can release alarm behavior, meaning bees will flicker their wings, exhibit alarm postures identical to guards, fly towards visual stimuli (moving or dark objects) and perhaps, sting. Alarm pheromone rapidly releases stinging behavior but the presence of a 
moving visual stimulus is usually required (Free, 1961; Ghent and Gary, 1962; Wager and Breed, 2000). Primer pheromones have longer lasting effects on behavior and physiology, and likely influence gene expression. Primer effects have not been reported for alarm pheromone, but there is recent evidence that exposure to IAA influences expression of at least one gene, the immediate early transcription factor $c$-Jun, in the antennal lobes of the bee brain (Alaux and Robinson, 2006).

Many alarm pheromone components act as attractants at low concentrations near the nest but at higher concentrations release attack behaviors or are repellent (Boch et al., 1970; Blum and Fales, 1988). Specific compounds of the pheromone blend vary in their effects on chemotaxis, flying and stinging (Pickett et al., 1982; Wager and Breed, 2000). The most abundant compound present in honey bee alarm pheromone, (Z)-11-eicosenol, elicits a synergistic response when combined with IAA and the mixture was as behaviorally active as an intact sting (Pickett et al., 1982). An unsaturated derivative of IAA was recently discovered in AHB, 3-methyl-2-buten-1-yl acetate, or 3M2BA (Hunt et al., 2003b). 3M2BA was as active as IAA for recruitment and mixed with IAA had a synergistic effect.

\section{Age-related changes and physiological correlates of defensive behavior}

Honey bees exhibit age-polyethism (reviewed by Robinson, 1992). Workers engage in withinnest tasks when young and spend the end of their lives foraging for pollen or nectar outside the nest. Young workers (nurse bees) feed brood with glandular secretions. Middle-age workers usually perform the in-nest tasks of comb building and food storing, and only a small proportion (10-15\%) engage in guarding behavior prior to becoming foragers (Moore et al., 1987; Hunt et al., 2003a). Bees that respond to a disturbance by stinging or flying out of the hive are similar in age to foragers (Breed et al., 1990; Huang et al., 1994). Older workers produce more venom and alarm pheromones (Boch and Shearer, 1966; Crewe and Hastings, 1976; Whiffler et al., 1988). In one study, IAA production peaked at about 2-3 weeks of age in workers but remained low in bees caged for 6 weeks (Boch and Shearer, 1966). Perhaps the caged bees were not exposed to stimuli necessary to initiate IAA biosynthesis or physiological changes associated with worker ovarian development in the queenless state inhibited production. Older workers (Allan et al., 1987) and older drones (Vetter and Visscher, 1997) exhibit higher EAG responses to alarm pheromone. Like workers, IAA repels drones in olfactometer assays (Becker et al., 2000). Workers older than 5-7 days also stung more readily upon electrical stimulation than young workers (Kolmes and Fergusson-Kolmes, 1989; Paxton et al., 1994).

Since age has an effect on individual defensive response and highly defensive AHB begin foraging at a younger age than EHB, Giray et al. (2000) experimentally increased the age of bees in colonies by dividing them to produce demographically old or young hives. They found higher colony stinging response in 'old' hives, for both AHB and EHB. In addition, stinging responses correlated with the rate of behavioral development (measured as the age at which a colony's bees take their first foraging flight) within EHB. The rate of behavioral development may influence defensive behavior by significantly increasing the proportion of 'physiologically old' bees. However, results of quantitative trait locus (QTL) mapping do not lend support to this conclusion because QTLs that were mapped that influence the trait 'age at first foraging', or AFF, were unlinked to QTLs that influence defensive behavior (Rueppell et al., 2004; Hunt et al., 1998, see below). The effect of rate of behavioral development on defensive behavior may be too small to be detected by QTL studies, or other QTLs remain to be characterized that have pleiotropic effects on these two traits.

The behavioral progression of bees correlates with juvenile hormone (JH) titer (Fluri et al., 1977; reviewed by Robinson and Vargo, 1997). JH generally increases throughout the adult stage in honey bees. Nurse bees usually have much lower JH titers than foragers, but JH levels 
decrease in older workers if they revert to nursing in response to experimental removal of nurses, and precocious foragers have elevated JH titers compared to same-age nurses. Some studies have suggested a positive correlation between JH titer and aggressivity. Injecting newly emerged bees with 15 or $50 \mu \mathrm{g}$ of JH III significantly reduced aggression of workers towards foreign queens 5 days later in a lab behavioral assay (Breed, 1983). JH treatment in this case was interpreted as causing a reduction in $\mathrm{JH}$ titer through negative feedback because $\mathrm{JH}$ treatment caused a reduction in corpora allata volume after 5 days. Applying the JH analog methoprene to newly emerged bees caused an increase in alarm pheromone production (Robinson, 1985) and increased the behavioral response to either IAA or 2-heptanone 5 days after treatment, but not the EAG response (Robinson, 1987). Methoprene may provide a more prolonged JH effect because of slower uptake and metabolism. In another study, guard bees and undertakers had higher JH levels than similar-age wax producers and food storers (Huang et al., 1994). But bees that stung a target after disturbance of the hive had JH levels equivalent to foragers. Pearce et al. (2001) also looked for a connection between JH levels and aggression using a nestmate-recognition assay in which 10 bees in an arena either reject or accept an introduced foreign bee. Assay results correlated with colony defensive response and showed lower aggression during the winter when $\mathrm{JH}$ levels are low in bees, as compared to summer. In general, bees classified as aggressive had higher JH levels but the comparisons were between bees of unknown age, and between winter and summer bees. There was no correlation between average colony JH level and aggression. Similarly, Robinson et al. (1987) found that highly defensive AHB did not have higher JH titers than low-defensive EHB.

Stress has the potential to increase aggressive behavior in both vertebrate and invertebrate species. JH levels seem to correlate with stress in young bees. One stressful treatment is to cage bees in the laboratory. Both mortality rate and JH biosynthesis varies inversely with the number of caged bees (Huang and Robinson, 1992; Moncharmont et al., 2003). Workers caged in isolation for 5 days exhibited more aggression towards foreign queens and had larger corpora allata than those caged in groups (Breed, 1983). Caging or cold-anesthetizing nurse bees caused an increase in JH titer within just $1 \mathrm{~h}$ (Lin et al., 2004). Foragers that were caged also showed a change in $\mathrm{JH}$ titer, but their $\mathrm{JH}$ levels either increased if they were initially low or fell if they were initially high. This indicates that JH levels do not correlate with stress in older bees. Decoupling stress and JH levels could provide a way to test whether JH or stress causes increased aggressivity in older bees. A virus was identified in the brains of worker bees attacking hornets presented at hive entrances that was not detectable in non-attacking nestmates (Fujiyuki et al., 2004, 2005). Subsequent studies showed that other stresses also caused elevated titers of this virus (Fujiyuki et al., 2006). All these observations raise the question of whether stress increases the defensive behavior. The sacrifice of stressed individuals in colony defense would be a good adaptive strategy because colonial animals such as bees require mechanisms to remove potentially infectious diseased individuals and the residual value of stressed individuals to the colony is relatively low.

\section{Possible roles of biogenic amines}

Comparisons of studies in different taxa can suggest some trends in the physiological correlates of aggression. In general, aggressive behavior is episodic. It involves short bouts of activity, and agonistic encounters can be stressful for all individuals involved. Aggressive interactions or stress can cause changes in titers of specific neurohormones or neurotransmitters. The basal levels of some of these compounds have been associated with a predisposition to engage in aggressive acts. Of course, studies involving biogenic amine applications or analyses of their levels are limited by the fact that the timing, amount and sites of neurotransmitter release, the receptor subtypes, and receptor densities can all vary independently to affect neural transmission and physiology (reviewed in Page and Erber, 2002). In addition, it is difficult to draw conclusions from comparisons involving diverse taxonomic groups because species differ 
in neural physiology and different motivations may be involved, such as competition, predation or defense. Despite all these caveats, some underlying patterns can be recognized.

Neuromodulatory systems associated with aggression in vertebrates include the biogenic amines serotonin (5-HT) and dopamine (DA), and the neurotransmitter, $\gamma$-aminobutyric acid (GABA) (Miczek et al., 2002). 5-HT levels in specific brain regions appear to play a central role as a negative regulator of aggression in vertebrate species as diverse as reptiles, fish, birds and mammals (Nelson and Chiavegatto, 2001; Summers et al., 2005; Wendland et al., 2006; Popova, 2006). In mammals, evidence from activity or polymorphisms of genes involved in serotonin metabolism and transport, serotonin receptors and results of breeding for nonaggressive behavior, all point to the role of the serotonergic system (Nelson and Chiavegatto, 2001; Popova, 2006).

5-HT also appears to play a role in agonistic behavior of arthropods. But in contrast to vertebrates, 5-HT levels are positively correlated with aggression in crustaceans (Huber et al., 1997; Kravitz, 2000; Kravitz and Huber, 2003; Panksepp et al., 2003) and response to 5-HT application may depend on dominance status (Yeh et al., 1996). 5-HT also may increase aggression in crickets (Dyakonova et al., 1999). Similarly, stress and inter-specific fighting resulted in increased 5-HT levels in an ant (Tarchalska et al., 1975). However, recent studies suggested that octopamine (OA) plays a more critical role in aggressive behavior of insects. Pharmacological studies showed that experience-dependent aggressive interactions in crickets were influenced by OA, but not 5-HT (Stevenson et al., 2005) and fighting caused an increase in OA but not 5-HT (Adamo et al., 1995). In bumblebee colonies, worker ovaries can develop at the end of the season and there is competition between workers for egg laying. Dominant bumblebees (those that either engaged in egg laying or aggressive acts) had higher OA levels than other individuals, but levels of 5-HT or DA were similar (Bloch et al., 2000). Another study involved a queenless ant species in which all workers in the colony have similar reproductive potential and compete for reproductive status. Dominant ants had higher OA, lower DA and equal 5-HT levels to subordinates (Cuvillier-Hot and Lenoir, 2006). The association of $\mathrm{OA}$ with insect aggression seems to make sense because $\mathrm{OA}$ is believed to prime insects for the 'fight or flight' response through a rise in cAMP or $\mathrm{Ca}^{2+}$ levels (Roeder, 2005).

In the honey bee brain, biogenic amine levels have not been correlated with stinging or guarding behaviors but OA application has been shown to affect olfactory conditioning, which is a component of guarding behavior (e.g., Erber et al., 1993; Menzel et al., 1999; Farooqui et al., 2003), and enhances nestmate recognition (Robinson et al., 1999), as well as sensitivity to specific odors during undertaker behavior (Spivak et al., 2003). Stress induced by restraining a forager by the leg causes brain levels of both OA and 5-HT to be elevated and peak in about 10 min (Harris and Woodring, 1992). In general, levels of 5-HT, OA and DA increase with age in adult bees but levels vary significantly between colonies (Fuchs et al., 1989; Harris and Woodring, 1992; Wagener-Hulme et al., 1999). There are earlier peaks in DA and 5-HT during the pupal stage and GABA and glutamate levels peak when bees are 10 days old, corresponding to the approximate age at which they are guarding or taking their first foraging flights. These peaks may reflect the role for these compounds in neural development (Fuchs et al., 1989; Taylor et al., 1992).

\section{Insights from laboratory assays}

Behaviors involved in colony defense are difficult to study out of social context, but lab assays have provided useful insights. Burrell and Smith used an isolated abdomen preparation to look at sting extension. Electromyogram activity of the abdomen was released by severing the ventral nerve chord and activity was highest in bees 5-7 days and older (Burrell and Smith, 1994). Abdomens from younger bees had a lower threshold for initiating sting extension by 
stimulation with a piezo electric buzzer, even though older bees are more likely to sting. OA injection reduced electromyogram activity during the stimulation trials but it increased the occurrence of full sting extension, an effect that lasted at least $3 \mathrm{~h}$ (Burrell and Smith, 1995). The authors suggested OA has multiple targets in the modulation of sting extension. Further evidence for central nervous system (CNS) inhibition of sting extension came from the repellent effect of vials that previously held a worker bee, which were then exposed to test bees. Vials that previously contained beheaded bees resulted in a longer-lasting repellent effect than those with intact bees (Balderrama et al., 1996), suggesting that the CNS inhibited sting extension and release of alarm pheromone.

Electrical stimulation of restrained bees has provided further insights into the physiology behind stinging. Morphine, but not other opioid peptides tested, caused a dose-dependent reduction of sting extension, but at a dosage much higher than typically used in vertebrate studies. Small doses of IAA applied to a vial containing five bees kept for $30 \mathrm{~min}$ increased subsequent voltage-induced sting extension, but larger doses of IAA resulted in a dosedependent reduction of sting extension. The reduction in sting extension could be reversed by the opioid antagonist nalaxone. These results suggested that an endogenous opioid system is present in honey bees and that IAA causes stress-induced analgesia (Nunéz et al., 1983, 1998). Endogenous morphine and pharmacological evidence of opioid receptor activity have been detected in other invertebrates in response to stress. It has been suggested that one function of the opioid system in diverse species, from protozoa to arthropods is to suppress avoidance of pain or danger to permit alternative behavioral responses (Dyakonova, 2001). Currently, no opioid receptors have been identified in insects. It is possible that morphine in the above experiment was binding to non-opioid receptors to cause the effects observed. Perhaps IAA stimulates release of neuropeptides and/or biogenic amines to ready the bee for 'fight or flight'. In mammals for example, a physiological "defense response" that includes increased respiration and heart rate was recently found to be dependent on the activity of the neuropeptide orexin (Zhang et al., 2006). Insect neuropeptides are often localized to specific neural circuits and act in concert with neurotransmitters to affect behavior (Nässel and Homberg, 2006). If physiological response to alarm pheromone is a result of neuropeptide release, it may be difficult to identify the receptors and ligands involved because these molecules evolve more rapidly than biogenic amine receptors (Hauser et al., 2006; Hummon et al., 2006).

Further evidence that alarm pheromone causes physiological readiness for 'fight or flight' comes from pioneering work showing that IAA causes a transient increase in respiration of caged bees, and that this increase correlates with colony defensive response (Southwick and Moritz, 1985). The metabolic reaction to IAA per bee increases with group size up to about 100 individuals. This group effect may be the result of secondary alarm pheromone release or behavioral interactions. Interestingly, mixtures of genotypes sometimes resulted in nonadditive interactions (Moritz and Southwick, 1987). The metabolic assay has been refined and used to evaluate the defensive behavior of AHB (Andere et al., 2002). High-defensive AHB also have an inherently higher respiration rate than EHB, but whether this difference is relevant to defensive behavior is unknown (Southwick, 1990; Harrison and Hall, 1993; Harrison et al., 2005).

Electrical stimulation has been used to elicit stinging from individual, unrestrained bees. In this assay, parallel wires are electrified and a suede piece of leather is placed beneath the wires for the bee to sting. Increasing voltage or current can be used to determine the threshold of response, and workers from more defensive colonies were shown to have lower response thresholds for stinging (Kolmes and Fergusson-Kolmes, 1989). However, colony environment also affects response thresholds. Low-defensive bees only had higher response thresholds when fostered in their natal colony; when cross-fostered in a defensive colony, their response thresholds were the same as the majority of bees in the colony (Paxton et al., 1994). However, 
another study in which restrained bees were electrically stimulated showed a significant difference in sting extension between patrilines of workers from a naturally mated queen in a common environment (Lenoir et al., 2006). Besides using restrained bees, the latter study also differed from that of Paxton et al. in that bees were collected upon emergence and kept in small groups of 70 individuals in the laboratory without a queen and tested 12 days later. In this situation, environmental effects were not sufficiently large to prevent detection of significant differences between patrilines. In addition to differences in thresholds of response, there were qualitative differences between patriline responses. During the four stimulation periods, some patrilines responded each time with the same degree of sting extension while others showed a habituation to the stimulus.

\section{Gene expression studies}

Honey bee defensive behavior responds to selective breeding. Robinson and Page (1988) detected a genetic component to individual guarding behavior and a number of studies have looked at the heritability of colony stinging behavior (reviewed by Collins and Rinderer, 1991; Stort and Gonçalves, 1991). A microarray experiment compared gene expression between age-matched full sister worker bees engaging in either comb building, guarding or "undertaker" behaviors. Undertakers are bees that remove corpses from the colony. Agematched comb builders differed from both guards and undertakers for expression of 248 cDNAs at $p<0.01$, which was 4.5 times more than expected by chance (Cash et al., 2005). But the number of genes differentially expressed between guards and undertakers (50) was similar to that expected by chance alone (56). Lack of differentiation in gene expression between guards and undertakers suggests that either expression differences are subtle, are limited to specific brain regions or life stages, or that similar gene expression is occurring in these two task groups. Both guards and undertakers are involved in removing bees from the hive based on olfactory cues, although the cues and actual behaviors are different for bees dealing with live versus dead bees.

Fruitflies can be selected for aggressive behavior in the context of competition for food resources or mating. Two studies recently identified candidate genes using expression profiling of lines selected for aggression in food competition. In the first study, 21 generations of selection for higher aggressivity resulted in a large (30-fold) response to the aggressive index. Differential expression of 474 and 775 genes was found between two aggressive lines and the control line ( $p<0.05$; Dierick and Greenspan, 2006). The 80 genes with the most significant expression differences had generally higher gene expression in aggressive lines, and included genes involved in muscle contraction, $\mathrm{Ca}^{2+}$ signaling, energy metabolism and cuticle formation. In the second study, 30 generations of bi-directional selection was performed. A whole-genome microarray identified 1083 transcripts that differed between low and high lines at a false discovery rate of 0.001 (Edwards et al., 2006). Some of these candidate genes were tested functionally by assessing the aggression scores of homozygous, p-element induced mutations within the genes. Surprisingly, 15 of 19 genes tested showed altered aggression in comparison to the coisogenic control line. There were some similar trends in these two studies. Neither selection regime resulted in a change in basal locomotor activity. The most surprising consensus was that neither study identified genes involved in biogenic amine metabolism, transporters or receptors, with the exception of Catecholamines up (Edwards et al., 2006) and did not include previously identified genes involved in Drosophila aggression. Candidate genes represented a spectrum of functional categories. It will be necessary to perform QTL mapping experiments in these populations to determine which changes in gene expression are causal regulators of aggressive behavior and which are coincidental or correlated responses to selection. It may be useful to test for differential expression of genes in guards versus nonguards or AHB versus EHB. 


\section{Epigenetics: The paternal effect on stinging behavior}

There have been numerous reports that the high-defensive colony stinging response of AHB is genetically dominant over the low-defensive EHB phenotype (see Stort and Gonçalves, 1991; DeGrandi-Hoffman et al., 1998; Guzmán-Novoa and Page, 1994; Guzmán-Novoa et al., 2002). However, data from four independent sets of reciprocal $F 1$ crosses revealed that colony stinging behavior shows a large paternal effect (Guzmán-Novoa et al., 2005). Crosses in which the African-derived colony was used to provide the father of the $\mathrm{F} 1$ workers resulted in colonies that were as defensive as the African type, indicating dominant gene effects. But reciprocal crosses with European paternity resulted in colonies that were intermediate between the parental types, showing additive gene effects. The paternal effect could be the result of genomic imprinting of maternal or paternal alleles, resulting expression that is dependent on the parental origin.

According to the genomic conflict theory, selection for imprinting effects are favored by multiple paternity, and also may be favored by haplo-diploidy (reviewed by Haig, 1992; Wood and Oakey, 2006). Alleles of some mammalian genes and genomic regions are known to be differentially methylated depending on parental origin, thus reducing or eliminating transcription of one parental allele. Methylation often is limited to specific tissues and early developmental stages (Wood and Oakey, 2006). Honey bees have active CpG methylation systems more similar to humans than to Drosophila (Wang et al., 2006). Imprinting effects on defensive behavior could be an example of intra-genomic conflict in which the fitness benefit that accrues from expression of the allele is not the same for the father as it is for the mother (Haig, 2000; Queller, 2003). Reduction in the expression of maternal alleles could reduce costs associated with too great of a defensive response because either all of the workers (if the queen is homozygous) or half of the workers (if the queen is heterozygous) in a colony would inherit the maternal allele. Preferential expression of paternal alleles, on the other hand, could lead to specialization of some patrilines in colony defense (Guzmán-Novoa et al., 2005). Another potential selective advantage for paternal effects involves fights between virgin queens. Normally, there is one queen in a honey bee colony, but when virgin queens emerge concurrently, they fight until one is eliminated. Paternal expression of genes involved in aggression in queens could confer a selective advantage for the patriline that carries them.

Results of studies reviewed above suggest a model for honey bee defensive behavior that includes behavioral interactions involving guards and release alarm pheromone release, which readies worker bees for 'fight or flight' (Fig. 1). Specific gene effects have not been identified as of yet, but progress towards identifying causal genes is discussed below.

\section{Quantitative trait loci influencing defensive behavior}

Mapping genes as QTLs has been useful for identifying genetic factors influencing aggressive behavior in a number of species but has been slow to identify causal genes (Flint, 2003; Anholt, 2004). QTL analysis involves testing for association between the inheritance of marker alleles and phenotypes. QTLs that influence colony stinging behavior were mapped in progeny of a F1 queen, which was the result of a cross between a low-defensive European colony and a high-defensive African-derived colony (Hunt et al., 1998). Each haploid drone from the F1 queen was the father of a colony (a backcross to a European queen). The colony phenotype used was the number of stings deposited in a leather "flag" waived in front of a colony, after 1 min of stinging activity. Several putative QTL were identified influencing the colony phenotype and three (sting1, sting2 and sting3) were later confirmed to influence defensive behavior of individual worker bees. Three sets of confirmation crosses were used. Each consisted of a family of backcross workers: daughters of an F1 queen mother and a haploid father from one of the two parental colonies used to make the F1 cross. Workers that were 
among the first few bees to sting a leather patch were collected and the process was repeated until about 100 bees were obtained from each family. Bees that stung were assayed for their genotypes at markers linked to sting 1 . In two studies, the ratio of high-defensive marker allele to the low-defensive allele was higher than the expected 1:1 in these 'responders' and significantly different from a control sample, confirming the influence sting 1 on individual defensive behavior (Guzmán-Novoa et al., 2002; Arechavaleta-Velasco et al., 2003). The other two QTL, sting2 and sting3, could not be tied to individual stinging behavior but all three QTLs influenced individual guarding behavior (Arechavaleta-Velasco et al., 2003). Putative QTLs that influence the levels of specific alarm pheromone components, and others that influence individual guarding behavior have also been identified but have not been tied to genomic sequence (Hunt et al., 1999; Arechavaleta-Velasco and Hunt, 2004).

\section{Candidate genes for honey bee defensive behavior}

Linkage maps are based on crossovers, and the size of the honey bee linkage maps revealed that the bee has the highest reported rate of meiotic recombination for any higher eukaryote (Hunt and Page, 1995; Solignac et al., 2004; Beye et al., 2006). A high recombination rate is fortuitous for QTL mapping studies because it increases resolution of confidence intervals for QTL location. Because of the bee's high recombination rate, it was possible to use the newly published genome sequence (HGSC, 2006) to narrow the search for genes involved in defensive behavior to a manageable number of candidate genes within the $97 \%$ confidence intervals for the three sting QTLs. Respectively for sting1, sting2 and sting3, there were only 50, 61 and 16 predicted peptides coded by the genomic DNA (Hunt et al., 2006). The average size of each confidence interval was about $40 \mathrm{cM}$ in genetic distance, but they did not cover extremely large physical distances. Fine-scale mapping to reduce confidence intervals to within $5 \mathrm{cM}$ would reduce the list of candidates to about five genes. In comparison, a $40 \mathrm{cM}$ distance in $M u s$ would have about 500 genes, and the same size region in Drosophila would contain about 2000 genes.

We can speculate as to which of the candidate genes are most likely to be influencing defensive behavior. Reported functions of orthologous genes in the literature provides some insights because many of the genes involved in regulation of CNS development, sensory tuning and neural signaling pathways are conserved across taxa. In addition, a small number (19) of the candidate genes have been tested by qRT-PCR for differences in transcript levels in adult bees between a high-defensive family and a low-defensive family (Hunt et al., 2006). Sting 1 accounted for more of the colony phenotypic variance (about 11\%) for numbers of stings than the other two QTLs. The 50 genes in this region provide an array of likely candidates. There are at least seven genes that are orthologs of genes involved in neuronal development and signaling (see Table 1). For example, 14-3-3 epsilon is a protein that is highly expressed in the nervous system and is involved in neurogenesis (Berg et al., 2003). Recent microarray expression and single nucleotide polymorphism (SNP) association studies in humans identified 14-3-3 epsilon as a potential susceptibility gene for suicide (Yanagi et al., 2005). A honey bee ortholog of the Drosophila gene tango is also present at sting1. This is a basic helix-loop-helix (bHLH) transcription factor that is important in neuronal development in Drosophila (Crews, 1998). Other bHLH transcription factors are sensors of environmental stimuli or endogenous hormones and can have multiple dimerization partners (Godlewski et al., 2006; Gorr et al., 2006). The region also contains the gene for huntingtin protein, which is a scaffolding protein that affects neuronal transcription and transport and repeats in this gene cause Huntington's chorea (Harjes and Wanker, 2003; $\mathrm{Li}$ and $\mathrm{Li}$, 2004). Of these three, transcription of Am14-3-3 was significantly higher (1.5-fold) in the high-defensive family of bees compared to the low-defensive family, but expression of other candidate genes also showed trends in the same direction (Hunt et al., 2006). 
Near the most likely position for sting2 is an arrestin, AmArr4. This gene is an ortholog of Dm/ arrl, which binds the light-activated form of the GPCR rhodopsin in the eye and recycles it. But arrl was recently found to be expressed in Drosophila antennae and null mutants are defective in olfaction of class I and II odorants (Merrill et al., 2005). This is a particularly interesting candidate, because of the involvement of both moving visual stimuli and olfaction in defensive behavior. AmArr4 also showed a non-significant trend towards higher expression (1.4-fold) in the defensive family of bees. Near the edge of the confidence interval for sting2 is the honey bee ortholog of the gene encoding the GABA-B-R1 receptor, which was expressed at a significantly lower level ( 0.63 -fold) in newly emerged defensive bees but not in older bees. GABA is the principal negative regulator of neural transmission in adult insects and is involved in neural development in pre-adult stages. The GABA-B-R1 receptor has also been shown to play specific roles in the patterns of interneuron activation in response to specific odors in the antennal lobe of Drosophila (Wilson and Laurent, 2005).

Sting 3 contained only 16 genes within the $97 \%$ confidence interval. A previous report indicated that the Cloned marker sequence lies near the $\mathrm{Am} 5-\mathrm{HT}_{7}$ serotonin receptor was linked to Sting3 but subsequent analyses showed that it was on a different chromosome (Hunt et al. 2006, and unpublished data). The sting 3 region containes two genes known to affect behavior and neural signaling in other species, the catalytic subunit of PKA and the ortholog of homer (Table 1). In mammals, homer proteins are key regulators of signal transduction in the brain and transcription and splicing of the homer 1 gene responds rapidly to synaptic activity (Bottai et al., 2002).

\section{Conclusions}

The defensive behavior of honey bees involves alerting to stimuli, social interactions, release of alarm pheromone, recruitment and attack. Our understanding of the physiology and genetics of this behavior is rudimentary but rapidly increasing. Study of other species suggests that neuropeptides and biogenic amines are likely involved. Alarm pheromone causes an increase in metabolic rate and the apparent induction of stress induced analgesia, possibly mediated by neuropeptides and/or biogenic amines. The adaptive significance for the chemical complexity of the honey bee alarm pheromone is unknown but synergistic effects between components have been detected and primer effects on behavior are possible. An intriguing finding from classical genetic studies is the occurrence of a paternal effect on colony stinging response. This raises the question of whether genomic imprinting is involved in the expression of key genes influencing this behavior. Candidate genes for stingl, which showed the strongest statistical association with stinging behavior, include a number of transcription factors involved in neural development and several genes involved in neuronal signaling. These genes could be tested for paternal expression patterns during CNS development. Genes near two other defensivebehavior QTLs suggest the involvement of G-protein signaling and synaptic regulation in defensive behavior. Analysis of candidate genes should lead to testable hypotheses to obtain evidence of gene functions. Differential expression assays, use of specific agonists and antagonists of GPCRs or experimentally changing gene expression by RNA interference could provide a better understanding of the underlying causes of honey bee defensive behavior.

\section{Acknowledgments}

I am grateful to Ernesto Guzmán-Novoa and Robert E. Page for years of collaboration and fruitful discussions, and to Andrew Ammons for useful comments on the manuscript. Past support from the National Science Foundation (IBN-0110842), NIH (R29 GM548580) and USDA (35302-10137) contributed towards our research. 


\section{References}

Adamo SA, Linn CE, Hoy RR. The role of neurohormonal octopamine during "fight or flight" behaviour in the field cricket Gryllus bimaculatus. Journal of Experimental Biology 1995;198:1691-1700. [PubMed: 7636443]

Alaux, C.; Robinson, GE. Effect of a releaser pheromone on behavior and brain gene expression in honey bees; Proceedings of the XV Congress, International Union for the Study of Social Insects; 2006; p. 236

Allan SA, Slessor KN, Winston ML, King GGS. The influence of age and task specialization on the production and perception of honey bee pheromones. Journal of Insect Physiology 1987;33:917-922.

Andere C, Palacio MA, Rodriguez EM, Figini E, Dominguez MT, Bedascarrasbure E. Evaluation of the defensive behavior of two honeybee ecotypes using a laboratory test. Genetics and Molecular Biology 2002;25:57-60.

Anholt RRH. Genetic modules and networks for behavior: lessons from Drosophila. BioEssays 2004;26:1299-1306. [PubMed: 15551265]

Arechavaleta-Velasco ME, Hunt GJ. Genotypic variation in the expression of guarding behavior and the role of guards in the defensive response of honey bee colonies. Apidologie 2003;34:439-447.

Arechavaleta-Velasco ME, Hunt GJ. Binary trait loci that influence honey bee guarding behavior. Annals of the Entomological Society of America 2004;97:177-183.

Arechavaleta-Velasco ME, Hunt GJ, Emore C. Quantitative trait loci that influence the expression of guarding and stinging behaviors of individual honey bees. Behavior Genetics 2003;33:357-364. [PubMed: 12837024]

Balderrama N, Nuñez J, Giurfa M, Torrealba J, De Albornoz EG, Almeida LO. A deterrent response in honeybee (Apis mellifera) foragers: dependence on disturbance and season. Journal of Insect Physiology 1996;42:463-470.

Becker MM, Bruckner D, Crewe R. Behavioural response of drone honey bees, Apis mellifera carnica, and Apis mellifera scutellata, to worker-produced pheromone components. Journal of Apicultural Research 2000;39:149-152.

Berg D, Holzmann C, Riess O. 14-3-3 proteins in the nervous system. Nature Reviews Neuroscience 2003;4:752-762.

Beye M, Gattermeier I, Hasselmann M, Gempe T, Scheioett M, Baines JF, Schlipalius D, Mougel F, Emore C, Rueppell O, Sirviö A, Guzmán-Novoa E, Hunt G, Solignac M, Page E Jr. Exceptionally high levels of recombination across the honey bee genome. Genome Research 2006;16:1339-1344. [PubMed: 17065604]

Bloch G, Simon T, Robinson GE, Hefetz A. Brain biogenic amines and reproductive dominance in bumble bees (Bombus terrestris). Journal of Comparative Physiology A 2000;186:261-268.

Blum, MS.; Fales, HM. Chemical releasers of alarm behavior in the honey bee: informational 'plethora' of the sting apparatus signal. In: Needham, GR.; Page, RE.; Delfinado-Baker, M.; Bowman, CE., editors. Africanized honey bees and bee mites. Wiley; New York: 1988. p. 141-148.

Boch R, Shearer A. Iso-pentyl acetate in stings of honeybees of different ages. Journal of Apicultural Research 1966;5:65-70.

Boch R, Shearer A, Petrasovits A. Efficacies of two alarm substances of the honey bee. Journal of Insect Physiology 1970;16:17-24. [PubMed: 5417706]

Bottai D, Guzowski JF, Schwarz MK, Kang SH, Xiao B, Lanahan A, Worley PF, Seeburg PH. Synaptic activity-induced conversion of intronic to exonic sequence in Homer 1 Immediate Early Gene Expression. The Journal of Neuroscience 2002;22:167-175. [PubMed: 11756499]

Breed MD. Correlations between aggressiveness and corpora allata volume, social isolation, age and dietary protein in worker honeybees. Insectes Sociaux 1983;30:482-495.

Breed MD, Rogers KB. The behavioral genetics of colony defense in honeybees: genetic variability for guarding behavior. Behavioral Genetics 1991;21:295-303.

Breed MD, Rogers KB, Hunley JA, Moore AJ. A correlation between guard behaviour and defensive response in the honeybee, Apis mellifera. Animal Behaviour 1988;37:515-516.

Breed MD, Robinson GE, Page RE. Division of labor during honey bee colony defense. Behavioral Ecology and Sociobiology 1990;27:395-401. 
Breed MD, Garry MF, Pearce AN, Hibbard BE, Bjostad LB, Page RE Jr. The role of wax comb in honey bee nestmate recognition. Animal Behaviour 1995;50:489-496.

Breed MD, Guzmán-Novoa E, Hunt GJ. Defensive behavior of honey bees: organization, genetics, and comparisons with other bees. Annual Review of Entomology 2004;49:271-298.

Burrell BD, Smith BH. Age- but not caste-related regulation of abdominal mechanisms underlying the sting reflex of the honey bee, Apis mellifera. Journal of Comparative Physiology A 1994;174:581592.

Burrell BD, Smith BH. Modulation of the honey bee (Apis mellifera) sting response by octopamine. Journal of Insect Physiology 1995;41:671-680.

Cash AC, Whitfield CW, Ismail N, Robinson GE. Behavior and the limits of genomic plasticity: power and replicability in microarray analysis of honeybee brains. Genes, Brain and Behavior 2005;4:267271.

Collins, AM.; Rinderer, TE. Genetics of defensive behavior I. In: Spivak, M.; Fletcher, JDC.; Breed, MD., editors. The "African” Honey Bee. Westview; Boulder, CO: 1991. p. 309-328.

Collins AM, Rinderer TE, Harbo JR, Bolten AB. Colony defense by Africanized and European honeybees. Science 1982;218:72-74. [PubMed: 17776713]

Crews S. Control of cell lineage-specific development and transcription by bHLH-PAS proteins. Genes and Development 1998;12:607-620. [PubMed: 9499397]

Crewe R, Hastings H. Production of pheromones by workers of Apis mellifera adansonii. Journal of Apicultural Research 1976;15:149-154.

Cuvillier-Hot V, Lenoir A. Biogenic amine levels, reproduction and social dominance in the queenless ant Streblognathus peetersi. Naturwissenschaften 2006;93:149-153. [PubMed: 16514515]

DeGrandi-Hoffman G, Collins A, Martin JH, Schmidt JO, Spangler HG. Nest defense behavior in colonies from crosses between Africanized and European honey bees (Apis mellifera L.) (Hymenoptera: Apidae). Journal of Insect Behavior 1998;11:37-45.

Dierick HA, Greenspan RJ. Molecular analysis of flies selected for aggressive behavior. Nature Genetics 2006;38:1023-1031. [PubMed: 16906161]

Dyakonova VE. Role of opioid peptides in behavior of invertebrates. Journal of Evolutionary Biochemistry and Physiology 2001;37:335-347.

Dyakonova VE, Schürmann F-W, Sakharov DA. Effects of serotonergic and opioidergic drugs on escape behaviours and social status of male crickets. Naturwissenschaften 1999;86:435-437. [PubMed: 10501691]

Edwards AC, Rollman SM, Morgan TJ, Mackay TFC. Quantitative genomics of aggressive behavior in Drosophila melanogaster. PLoS Genetics 2006;2:1386-1395.

Erber J, Klopenburg P, Scheidler A. Neuromodulation by serotonin and octopamine in the honeybee: behavior, neuroanatomy and electrophysiology. Experientia 1993;49:1073-1083.

Farooqui T, Robinson K, Vaessin H, Smith BH. Modulation of early olfactory processing by an octopaminergic reinforcement pathway in the honeybee. The Journal of Neuroscience 2003;23:53705380. [PubMed: 12832563]

Flint J. Analysis of quantitative trait loci that influence animal behavior. Journal of Neurobiology 2003;54:46-77. [PubMed: 12486698]

Fluri P, Wille H, Gerig L, Lüscher M. Juvenile hormone, vitellogenin and haemocyte composition in winter worker honeybees (Apis mellifera). Experientia 1977;33:1240-1241.

Free JB. The stimuli releasing the stinging response of honeybees. Animal Behaviour 1961;9:193-196.

Frumhoff PC, Baker J. A genetic component to division of labour within honey bee colonies. Nature 1988;333:358-361.

Fuchs E, Dustmann JH, Stadler H, Schürmann FW. Neuroactive compounds in the brain of the honeybee during imaginal life. Comparative Biochemistry and Physiology C 1989;92:337-342.

Fujiyuki T, Takeuchi H, Ono M, Ohka S, Sasaki T, Nomoto A, Kubo T. Novel insect picorna-like virus identified from the brains of aggressive worker honeybees. Journal of Virology 2004;78:1093-1100. [PubMed: 14722264]

Fujiyuki T, Takeuchi H, Ono M, Ohka S, Sasaki T, Nomoto A, Kubo T. Kakugo virus from brains of aggressive worker honeybees. Advances in Virus Research 2005;65:1-27. [PubMed: 16387192] 
Fujiyuki T, Ohka S, Takeuchi H, Ono M, Nomoto A, Kubo T. Prevalence and phylogeny of Kakugo virus, a novel insect picorna-like virus that infects the honeybee (Apis mellifera L.), under various colony conditions. Journal of Virology 2006;80:11528-11538. [PubMed: 16971448]

Ghent RL, Gary NE. A chemical alarm releaser in honey bee stings (Apis mellifera L.). Psyche 1962;69:16.

Giray T, Guzmán-Novoa E, Aron CW, Zelinsky B, Fahrbach SE, Robinson GE. Genetic variation in worker temporal polyethism and colony defensiveness in the honey bee, Apis mellifera. Behavioral Ecology 2000;11:44-55.

Godlewski J, Wang S, Wilson TG. Interaction of bHLH-PAS proteins involved in juvenile hormone reception in Drosophila. Biochemical and Biophysical Research Communications 2006;342:13051311. [PubMed: 16516852]

Gorr TA, Gassman M, Wappner P. Sensing and responding to hypoxia via HIF in model invertebrates. Journal of Insect Physiology 2006;52:349-364. [PubMed: 16500673]

Guzmán-Novoa E, Page RE Jr. Genetic dominance and worker interactions affect honeybee colony defense. Behavioral Ecology 1994;5:91-97.

Guzmán-Novoa E, Hunt GJ, Uribe JL, Smith C, Arechavaleta-Velasco ME. Confirmation of QTL effects and evidence of genetic dominance of honeybee defensive behavior: results of colony and individual behavioral assays. Behavior Genetics 2002;32:95-102. [PubMed: 12036115]

Guzmán-Novoa E, Hunt GJ, Uribe-Rubio JL, Prieto-Merlos D. Genotypic effects of honey bee (Apis mellifera) defensive behavior at the individual and colony levels: the relationship of guarding, pursuing and stinging. Apidologie 2004;35:15-24.

Guzmán-Novoa E, Hunt GJ, Page RE, Uribe-Rubio JL, Prieto-Merlos D, Becerra-Guzmán F. Paternal effects on the defensive behavior of honey bees. Journal of Heredity 2005;63:1-5.

Haig D. Genomic imprinting and the theory of parent-offspring conflict. Seminars in Cell and Developmental Biology 1992;3:153-160.

Haig D. The kinship theory of genomic imprinting. Annual Review of Ecology and Systematics 2000;31:9-32.

Harjes P, Wanker EE. The hunt for huntingtin function: Interaction partners tell many different stories. Trends in Biochemical Sciences 2003;28:425-433. [PubMed: 12932731]

Harrison JF, Hall HG. African-European honeybee hybrids have low nonintermediate metabolic capacities. Nature 1993;363:258-260.

Harris JW, Woodring J. Effects of stress, age, season, and source colony on levels of octopamine, dopamine and serotonin in the honey bee (Apis mellifera L.) brain. Journal of Insect Physiology 1992;38:29-35.

Harrison JF, Taylor OR Jr. Hall HG. The flight physiology of reproductives of Africanized, European, and hybrid honeybees (Apis mellifera). Physiological and Biochemical Zoology 2005;78:153-162. [PubMed: 15778935]

Hauser F, Cazzamali G, Williamson M, Blenau W, Grimmelikhuizen CJP. A review of neurohormone GPCRs present in the fruitfly Drosophila melanogaster and the honey bee Apis mellifera. Progress in Neurobiology 2006;80:1-19. [PubMed: 17070981]

Honey Bee Genome Sequencing Consortium. Insights into social insects from the genome of the honeybee, Apis mellifera. Nature 2006;443:931-949. [PubMed: 17073008]

Huang Z-Y, Robinson GE. Honeybee colony integration: Worker-worker interactions mediate hormonally regulated plasticity in division of labor. Proceedings National Academy of Science USA 1992;89:11726-11729.

Huang Z-Y, Robinson GE, Borst DW. Physiological correlates of division of labor among similarly aged honey bees. Journal of Comparative Physiology A 1994;174:731-739.

Huber R, Smith K, Delago A, Isaksson K, Kravitz EA. Serotonin and aggressive motivation in crustaceans: altering the decision to retreat. Proceedings of the National Academy of Science USA 1997;94:5939-5942.

Hummon AB, Richmond TA, Verleyen P, Baggerman G, Huybrechts J, Ewing MA, Vierstraete E, Rodriguez-Zas SL, Schoofs L, Robinson GE, Sweedler JV. From the genome to the proteome: uncovering peptides in the Apis brain. Science 2006;314:647-649. [PubMed: 17068263] 
Hunt GJ, Page RE Jr. A linkage map of the honeybee, Apis mellifera, based on RAPD markers. Genetics 1995;139:1371-1382. [PubMed: 7768445]

Hunt GJ, Guzmán-Novoa E, Fondrk MK, Page RE Jr. Quantitative trait loci for honeybee stinging behavior and body size. Genetics 1998;148:1203-1213. [PubMed: 9539435]

Hunt GJ, Collins AM, Rivera R, Page RE Jr. Guzmán-Novoa E. Quantitative trait loci for honeybee alarm pheromone production. Journal of Heredity 1999;90:585-589. [PubMed: 10544503]

Hunt GJ, Guzmán-Novoa E, Uribe-Rubio JL, Prieto-Merlos D. Genotype by environment interactions in honey bee guarding behavior. Animal Behaviour 2003a;66:469-477.

Hunt GJ, Wood KV, Guzmán-Novoa E, Lee HD, Rothwell AP, Bonham CC. Discovery of 3methyl-2buten-1-yl acetate, a new alarm component in the sting apparatus of Africanized honeybees. Journal of Chemical Ecology 2003b;29:453-463. [PubMed: 12737269]

Hunt GJ, Amdam GV, Schlipalius D, Emore C, Sardesai N, Williams CE, Rueppell O, Guzmán-Novoa E, Arechavaleta-Velasco M, Chandra S, Fondrk MK, Beye M, Page RE Jr. Behavioral genomics of honeybee foraging and nest defense. Naturwissenschaften. 2006in press, doi:10.1007/ s00114-006-0183-1

Kolmes SA, Fergusson-Kolmes LA. Measurements of stinging behaviour in individual worker honeybees (Apis mellifera L.). Journal of Apicultural Research 1989;28:71-78.

Kravitz EA. Serotonin and aggression: insights gained from a lobster model system and speculations on the role of amine neurons in a complex behavior. Journal of Comparative Physiology A 2000;186:221-238.

Kravitz EA, Huber R. Aggression in invertebrates. Current Opinion in Neurobiology 2003;13:736-743. [PubMed: 14662376]

Lenoir J-C, Laloi D, Dechaume-Moncharmont F-X, Solignac M, Pham M-H. Intra-colonial variation of the sting extension response in the honey bee Apis mellifera. Insectes Sociaux 2006;53:80-85.

Lensky Y, Cassier P. The alarm pheromones of queen and worker honey bees. Bee World 1995;76:119129.

Li S-H, Li X-J. Huntingtin-protein interactions and the pathogenesis of Huntington's disease. Trends in Genetics 2004;3:146-154. [PubMed: 15036808]

Lin H, Dusset C, Huang ZY. Short-term changes in juvenile hormone titers in honey bee workers due to stress. Apidologie 2004;35:319-327.

Maschwitz UW. Alarm substances and alarm behaviour in social hymenoptera. Nature 1964;204:324327.

Menzel R, Heyne A, Kinzel C, Gerber B, Fiala A. Pharmacological dissociation between the reinforcing, sensitizing, and response-releasing functions of rewarad in honeybee classical conditioning. Behavioral Neuroscience 1999;113:744-754. [PubMed: 10495082]

Merrill CE, Sherertz TM, Walker WB, Zwiebel LJ. Odorant-specific requirements for arrestin function in Drosophila olfaction. Journal of Neurobiology 2005;63:15-28. [PubMed: 15627264]

Miczek KA, Fish EW, de Bold JF, de Almeida RMM. Social and neural determinants of aggressive behavior: pharmacotherapeutic targets at serotonin, dopamine and g-aminobutyric acid systems. Psychopharmacology 2002;163:434-458. [PubMed: 12373445]

Moncharmont F-XD, Decourtye A, Hennequet-Hantier C, Pons O, Pham-Delégue M-H. Statistical analysis of honeybee survival after chronic exposure to insecticides. Environmental Toxicology and Chemistry 2003;22:3088-3094. [PubMed: 14713054]

Moore AJ, Breed MD, Moor MJ. The guard honey bee: ontogeny and behavioral variability of workers performing a specialized task. Animal Behaviour 1987;35:1159-1167.

Moritz RFA, Southwick EE. Phenotype interactions in group behavior of honey bee workers (Apis mellifera L.). Behavioral Ecology and Sociobiology 1987;21:53-57.

Nässel DR, Homberg U. Neuropeptides in interneurons of the insect brain. Cell Tissue Research 2006;326:1-24. [PubMed: 16761145]

Nelson RJ, Chiavegatto S. Molecular basis of aggression. Trends in Neuroscience 2001;24:713-719.

Nunéz JA, Maldonado H, Miralto A, Balderrama N. The stinging response of the honeybee: effects of morphine, naloxone and some opioid peptides. Pharmacology Biochemistry and Behavior 1983;19:921-924. 
Nunéz JA, Almeida L, Balderrama N, Giurfa M. Alarm pheromone induces stress analgesia via an opioid system in the honeybee. Physiology and Behavior 1998;63:75-80.

Page RE Jr. Erber J. Levels of behavioral organization and the evolution of division of labor. Naturwissenschaften 2002;89:91-106. [PubMed: 12046634]

Page RE, Robinson GE. The genetics of division of labour in honey bee colonies. Advances in Insect Physiology 1991;23:117-169.

Panksepp JB, Yue Z, Drerup C, Huber R. Amine neurochemistry and aggression in crayfish. Microscopy Research and Technique 2003;60:360-368. [PubMed: 12539165]

Paxton RJ, Sakamoto CH, Rugiga FCN. Modification of honey bee (Apis mellifera L.) stinging behaviour by within-colony environment and age. Journal of Apicultural Research 1994;33:75-82.

Pearce AN, Huang ZY, Breed MD. Juvenile hormone and aggression in honey bees. Journal of Insect Physiology 2001;47:1243-1247. [PubMed: 12770175]

Pickett JA, Williams IH, Martin AP. (Z)-11-eicosen-1-ol, an important new pheromonal component from the sting of the honey bee, Apis mellifera L. (Hymenoptera, Apidae). Journal of Chemical Ecology 1982;8:163-175.

Popova NK. From genes to aggressive behavior: the role of serotonergic system. Bioessays 2006;28:495503. [PubMed: 16615082]

Queller DC. Theory of genomic imprinting conflict in social insects. BMC Evolutionary Biology 2003:3. [PubMed: 12590655]

Robinson GE. Effects of a juvenile hormone analogue on honey bee foraging behaviour and alarm pheromone production. Journal of Insect Physiology 1985;31:277-282.

Robinson GE. Modulation of alarm pheromone perception in the honey bee: evidence for division of labor based on hormonally regulated response thresholds. Journal of Comparative Physiology A 1987;160:613-619.

Robinson GE. Regulation of division of labor in insect societies. Annual Review of Entomology 1992;37:637-665.

Robinson GE, Page RE Jr. Genetic determination of guarding and undertaking in honey-bee colonies. Nature 1988;333:356-358.

Robinson GE, Vargo EL. Juvenile hormone in adult eusocial hymenoptera: gonadotropin and behavioral pacemaker. Archives of Insect Biochemistry and Physiology 1997;35:559-583. [PubMed: 9210289]

Robinson GE, Strambi A, Strambi C, Paulino-Simões ZL, Tozeto SO, Barbosa JMN. Juvenile hormone titers in European and Africanized honey bees in Brazil. General and Comparative Endocrinology 1987;66:457-459. [PubMed: 3609717]

Robinson GE, Heuser LM, LeConte Y, Lenquette F, Hollingworth RM. Neurochemicals aid bee nestmate recognition. Nature 1999;399:534-535.

Roeder T. Tyramine and octopamine: Ruling behavior and metabolism. Annual Review of Entomology 2005;50:447-477.

Rueppell O, Pankiw T, Nielsen DI, Fondrk MK, Beye M, Page RE Jr. The genetic architecture of the behavioural ontogeny of foraging in honeybee workers. Genetics 2004;167:1767-1779. [PubMed: 15342515]

Schneider SS, DeGrandi-Hoffman G, Smith DR. The African honey bee: factors contributing to a successful biological invasion. Annual Review of Entomology 2004;49:351-376.

Slessor KN, Winston ML, Le Conte Y. Pheromone communication in the honeybee (Apis mellifera L.). Journal of Chemical Ecology 2005;31:2731-2745. [PubMed: 16273438]

Solignac M, Vautrin D, Baudry E, Mougel F, Loiseau A, Cornuet J-M. A microsatellite-based linkage map of the honeybee, Apis mellifera L. Genetics 2004;167:253-262. [PubMed: 15166152]

Southwick EE. Comparative energy balance in groups of Africanized and European honey bees: ecological implications. Comparative Biochemistry and Physiology 1990;97:1-8. [PubMed: 2123762]

Southwick EE, Moritz RFA. Metabolic response to alarm pheromone in honey bees. Journal of Insect Physiology 1985;31:389-392. 
Spivak M, Masterman R, Ross R, Mesce KA. Hygienic behavior in the honey bee (Apis mellifera L.) and the modulatory role of octopamine. Journal of Neurobiology 2003;55:341-354. [PubMed: 12717703]

Stevenson PA, Dyakonova V, Rillich J, Schildberger K. Octopamine and experience-dependent modulation of aggression in crickets. The Journal of Neuroscience 2005;25:1431-1441. [PubMed: 15703397]

Stort, AC.; Gonçalves, LS. Genetics of defensive behavior II. In: Spivak, M.; Fletcher, JDC.; Breed, MD., editors. The "African" Honey Bee. Westview; Boulder, CO: 1991. p. 329-356.

Summers CH, Korzan WJ, Lukkes JL, Watt MJ, Forster GL, Øverli Ø, Höglund E, Larson ET, Ronan PJ, Matter JM, Summers TR, Renner KJ, Greenberg N. Does serotonin influence aggression? Comparing regional activity before and during social interaction. Physiological and Biochemical Zoology 2005;78:679-694. [PubMed: 16059845]

Tarchalska B, Kostowski W, Markowska L, Markiewicz L. On the role of serotonin in aggressive behaviour of ants genus Formica. Polish Journal of Pharmacology and Pharmacy 1975;27:237239. [PubMed: 1239749]

Taylor DJ, Robinson GE, Logan BJ, Laverty R, Mercer AR. Changes in brain amine levels associated with the morphological and behavioural development of the worker honeybee. Journal of Comparative Physiology A 1992;170:715-721.

Vetter RS, Visscher PK. Influence of age on antennal response of male honey bees, Apis mellifera, to queen mandibular pheromone and alarm pheromone component. Journal of Chemical Ecology 1997;23:1867-1880.

Visscher PK, Vetter RS, Robinson GE. Alarm pheromone perception in honey bees is decreased by smoke (Hymenoptera: Apidae). Journal of Insect Behavior 1995;8:11-18.

Wagener-Hulme C, Kuehn JC, Schulz DJ, Robinson GE. Biogenic amines and division of labor in honey bee colonies. Journal of Comparative Physiology A 1999;184:471-479.

Wager BR, Breed MD. Does honey bee sting alarm pheromone give orientation information to defensive bees? Annals of the Entomological Society of America 2000;93:1329-1332.

Wang Y, Jorda M, Jones PL, Maleszka R, Ling X, Robertson HM, Mizzen CA, Peinado MA, Robinson GE. Functional CpG methylation system in a social insect. Science 2006;314:645-647. [PubMed: 17068262]

Wendland JR, Lesch K-P, Newman TK, Timme A, Gachot-Neveu H, Thierry B, Suomi SJ. Differential functional variability of serotonin transporter and monoamine oxidase A genes in Macaque species displaying contrasting levels of aggression-related behavior. Behavior Genetics 2006;36:163-172. [PubMed: 16402281]

Whiffler LA, Drusedau MUH, Crewe RM, Hepburn HR. Defensive behaviour and the division of labour in the African honeybee (Apis mellifera scutellata). Journal of Comparative Physiology A 1988;163:401-411.

Whitfield CW, Behura SK, Berlocher SH, Clark AG, Johnston JS, Sheppard WS, Smith DR, Suarez AV, Weaver D, Tsutsui ND. Thrice out of Africa: ancient and recent expansions of the honey bee, Apis mellifera. Science 2006;314:642-645. [PubMed: 17068261]

Wilson, EO. The Insect Societies. Belknap/Harvard University Press; Cambridge, MA: 1971. p. 548

Wilson RI, Laurent G. Role of GABAergic inhibition in shaping odor-evoked spatiotemporal patterns in the Drosophila antennal lobe. The Journal of Neuroscience 2005;25:9069-9079. [PubMed: 16207866]

Wood AJ, Oakey RJ. Genomic imprinting in mammals: emerging themes and established theories. PLoS Genetics 2006;2:1677-1685.

Yanagi M, Shirakawa O, Kitamura N, Okamura K, Sakurai K, Nishiguchi N, Hashimoto T, Nushida H, Ueno Y, Kanbe D, Kawamura M, Araki K, Nawa H, Maeda K. Association of 14-3-3 E gene haplotype with completed suicide. Journal of Human Genetics 2005;50:210-216. [PubMed: 15838597]

Yeh SR, Fricke RA, Edwards DH. The effect of social experience on serotonergic modulation of the escape circuit of crayfish. Science 1996;271:366-369. [PubMed: 8553075] 
Zhang W, Shimoyama M, Fukuda Y, Kuwaki T. Multiple components of the defense response depend on orexin: evidence from orexin knockout mice and orexin neuron-ablated mice. Autonomic Neuroscience: Basic and Clinical 2006;126:139-145. 


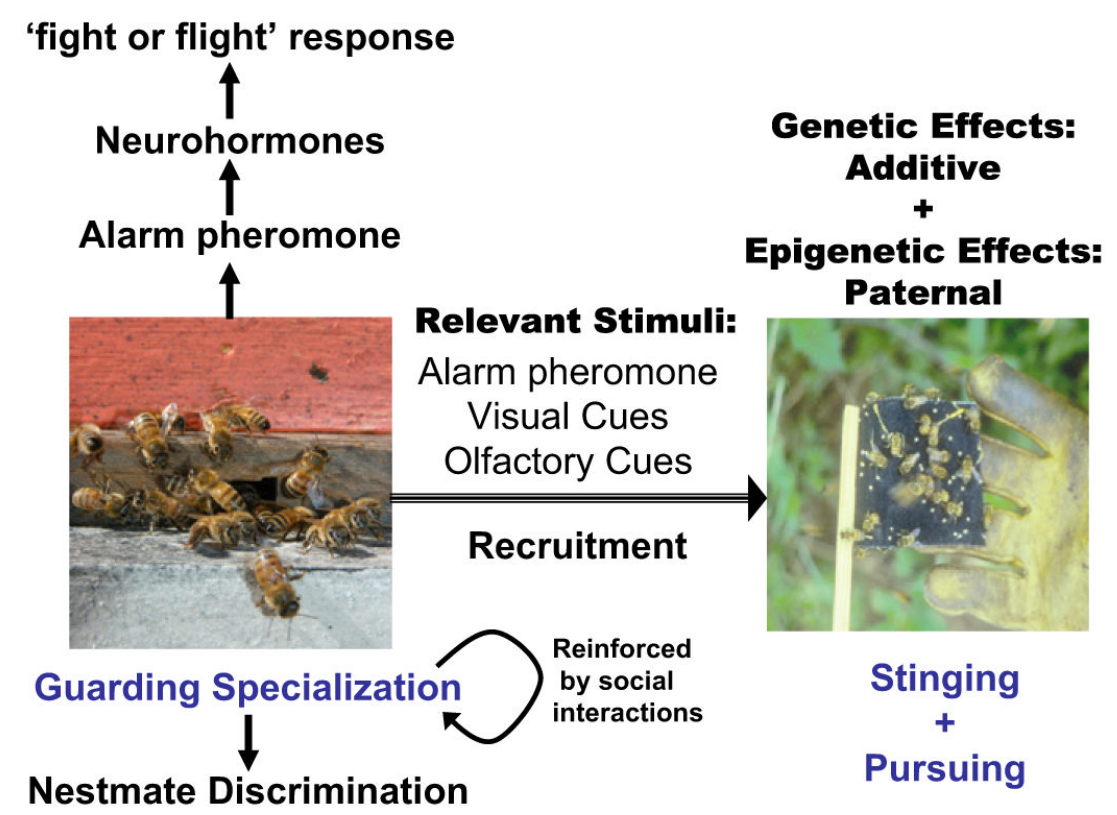

Fig. 1.

A conceptual model of honey bee defensive behavior. Guard bee specialization is influenced by genetic effects and social interactions. Guards release alarm pheromone when they become alerted, resulting in release of neurohormones (neuropeptides or biogenic amines) that influences the 'fight or flight' response analogous to that of vertebrates, which includes increased metabolic rate and stress-induced analgesia. The result is a release of flight activity, searching for visual targets, and stinging behavior. Both additive and paternal genetic effects on whole-colony stinging behavior have been demonstrated, suggesting that imprinted gene expression affects defensive behavior. 


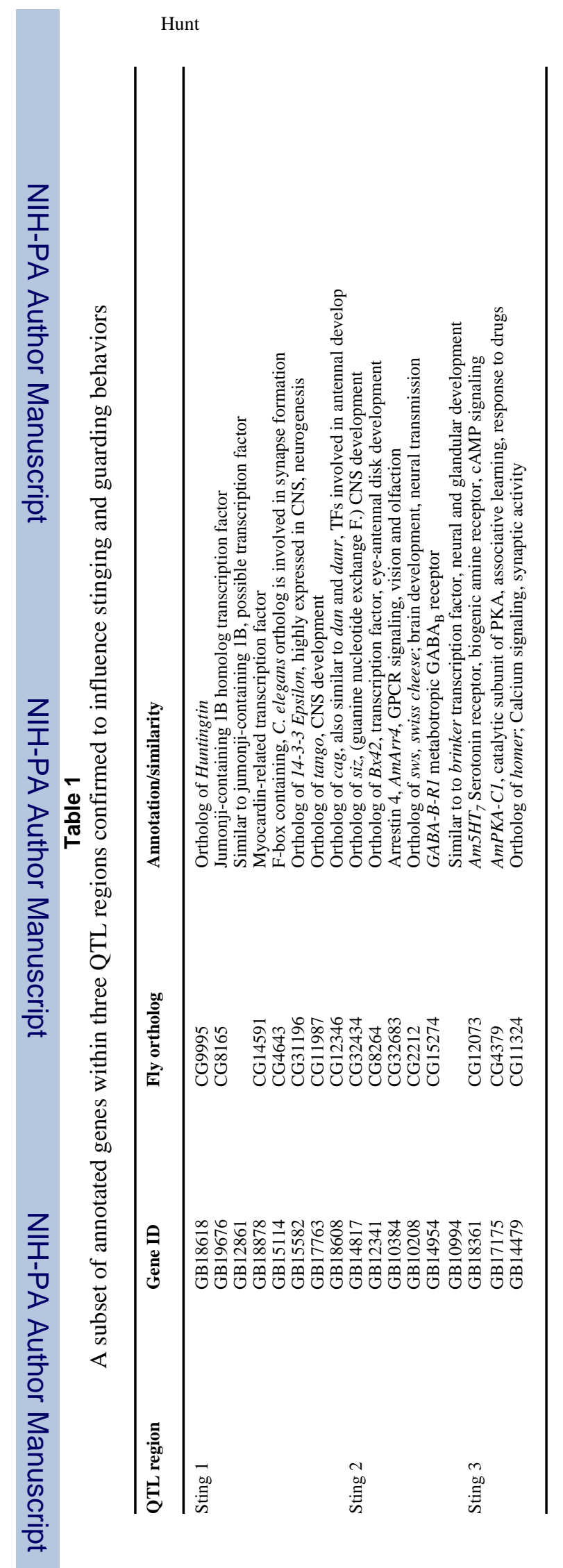

Page 19 